\title{
ANALISIS MODEL PENGGUNAAN AIR TANAH DANGKAL DI WILAYAH JAKARTA SELATAN
}

\author{
Henita Rahmayanti
}

\begin{abstract}
Abstrak
Tujuan penelitian ini membuat model penggunaan air tanah dangkal untuk keberlanjutan daya dukung perkotaan di wilayah Jakarta Selatan. Berdasarkan hasil simulasi dan asumsi yang berlaku dalam permodelan, kondisi air tanah dangkal di wilayah Jakarta Selatan jika tidak dilakukan intervensi maka tidak akan mampu mendukung kehidupan masyarakat di wilayah Jakarta Selatan, namun jika dilakukan intervensi maka ketersediaan air tanah dangkal akan mampu mendukung kehidupan masyarakat Jakarta Selatan.
\end{abstract}

Kata kunci : air tanah dangkal, daya dukung perkotaan, efisiens

\section{PENDAHULUAN}

Sebuah kota merupakan pusat perekonomian dan segala aktivitas manusia. Hal ini mengakibatkan meningkatnya arus urbanisasi ke wilayah perkotaan karena beberapa sebab, antara lain karena kebutuhan akan pendidikan, perekonomian, dan hiburan. Sementara pertumbuhan penduduk perkotaan sendiri menunjukkan peningkatan yang menyebabkan berbagai permasalahan kompleks, baik masalah sosial maupun masalah lingkungan.

Kotamadya Jakarta Selatan sebagai salah satu wilayah adminstrasi Propinsi DKI Jakarta yang merupakan ibukota negara Republik Indonesia mempunyai magnet yang luar biasa bagi penduduk Indonesia. Sebagai pusat kegiatan negara tentunya segala aktivitas perekonomian, perdagangan, pendidikan, dan pembangunan terpusat di Propinsi DKI Jakarta.

\footnotetext{
Henita Rahmayanti,Dra,M.Si

Staff Pengajar Jurusan Teknik Sipil

Fakultas Teknik Universitas Negeri Jakarta
} 
Pembangunan yang terus berlangsung tersebut menghadapi suatu tantangan yaitu keterbatasan lahan untuk pembangunan. Hal tersebut mengakibatkan lahan-lahan bervegetasi seperti jalur hijau, taman kota, pekarangan, dan hutan telah banyak difungsikan sebagai pertokoan, pemukiman, perkantoran, tempat rekreasi jalan, dan industri. Sedangkan di sisi lain Ruang Terbuka Hijau mempunyai peranan yang sangat penting sebagai daerah resapan air.

Sesuai dengan amanat Undang-undang Nomor 26 Tahun 2007 tentang Penataan Ruang disyaratkan ruang terbuka hijau sebesar 30\% untuk kota, dengan perincian 20\% RTH publik dan 10\% privat. Terkait hal tersebut maka Pemerintah kota Jakarta Selatan mengambil kebijakan yang dituangkan dalam Rencana Tata Ruang Wilayah (RTRW) kotamadya Jakarta Selatan untuk meningkatkan ruang terbuka hijau sebesar 0,5\% per tahun.

Berkurangnya ruang terbuka hijau yang ada, secara otomatis akan mengurangi laju penyerapan air tanah dangkal yang berarti akan mengakibatkan menurunnya volume air tanah dangkal. Di sisi lain pertumbuhan penduduk yang terus meningkat membawa konsekuensi pada menurunnya ruang terbuka hijau, seperti yang diutarakan pada pembahasan di atas. Padahal Kotamadya Jakarta Selatan yang diperuntukkan sebagai kawasan permukiman, dengan menggunakan air tanah dangkal untuk keperluan permukiman tersebut.

Berkaitan dengan pertumbuhan kota dan keberlanjutannya terkait daya dukung perkotaan, dijelaskan dalam Budihardjo (1999) bahwa kota yang berkelanjutan adalah daerah perkotaan yang mampu berkompetisi dalam kondisi ekonomi global dan mampu mempertahankan vitalitas budaya serta lingkungan. Dalam makalah ini, aspek keberlanjutan lingkungan dikaitkan dengan pemanfaatan air tanah dangkal yang mempengaruhi daya dukung lingkungan perkotaan.

Air merupakan salah satu sumberdaya alam utama dalam kehidupan untuk manusia, hewan, dan tumbuhan. Di dalam sistem hidrologi secara alamiah keberadaan air tanah di suatu wilayah harus seimbang antara masukan dan keluaran, dengan masukan air tanah dangkal berasal dari air hujan.

Jika penggunaan air tanah dangkal dibiarkan saja tanpa adanya intervensi sebagai suatu upaya untuk melakukan efisiensi maka daya dukung lingkungan akan menurun. Oleh 
sebab itu diperlukan gambaran mengenai manfaat atau peran dari efisiensi dari intervensi tersebut pada masa yang akan datang.

\section{Permasalahan}

Pertambahan jumlah penduduk merupakan salah satu faktor mendorong meningkatnya penggunaan air sehingga mempengaruhi volume air tanah dangkal. Penambahan volume air dipengaruhi oleh peningkatan luas RTH. Terdapat kesenjangan antara penggunaan air dan volume. Kondisi ini jika diperlakukan sebagai bussiness as usual maka akan menyebabkan ketidakberlanjutan sehingga diperlukan intervensi.

\section{Story to structure:}

Simulasi mengenai efisiensi air tanah dangkal untuk keberlanjutan daya dukung perkotaan untuk wilayah Jakarta Selatan didasarkan pada data sekunder yang bersumber dari BPS dan penelitian sebelumnya. Data dari BPS tahun 2009 yang digunakan adalah jumlah penduduk, jumlah kematian, dan jumlah kelahiran di Kotamadya Jakarta Selatan. Komposisi jumlah penduduk, jumlah kematian, dan jumlah kelahiran di Kotamadya Jakarta Selatan dapat dilihat pada Tabel 1.

Tabel 1. Jumlah penduduk, jumlah kematian, jumlah kelahiran di Jakarta Selatan

\begin{tabular}{|c|c|c|c|}
\hline Tahun & Jumlah Penduduk & Laju kelahiran & Laju kematian \\
\hline 2003 & 866.515 & 4.634 & 3.465 \\
\hline 2004 & 883.817 & 4.423 & 3.035 \\
\hline 2005 & 882.451 & 4.231 & 3.523 \\
\hline 2006 & 892.059 & 4.367 & 3.651 \\
\hline 2007 & 894.784 & 4.470 & 3.589 \\
\hline 2008 & 914.951 & 4.441 & 3.598 \\
\hline
\end{tabular}

Sumber : BPS (2009)

Luas ruang terbuka hijau di DKI Jakarta adalah seluas 1748,76 ha. Berdasarkan kebijakan Pemda Kotamadya Jakarta Selatan, setiap tahunnya akan ditambah ruang terbuka hijau seluas $0,5 \%$ dari luas wilayah administrasi Kotamadya Jakarta Selatan yang seluas 14.573 ha. Kemampuan ruang terbuka hijau di Kotamadya Jakarta Selatan dalam 
menyerap dan menghasilkan air tanah permukaan adalah sebanyak 15.000.000 liter per tahun (Hidayat, 2009)

Untuk menghitung jumlah kebutuhan air yang akan digunakan oleh penduduk setiap harinya maka akan digunakan beberapa data sekunder yang berasal dari beberapa penelitian yang telah dilakukan. Rata-rata kebutuhan air per orang dalam satu hari adalah 175 liter (DGTL, 2007).

Terkait dengan konsep daur ulang air sebagai suatu intervensi atau kebijakan yang diambil adalah konsep daur ulang yang dikembangkan oleh N.S.W Departement of Health. Konsep tersebut mengintegrasikan saluran air buangan ke penampungan untuk dilakukan-

filterisasi dan kemudian didistribusikan kembali ke saluran air khusus hasil air daur ulang.

Secara visualisasi konsep daur ulang air adalah sebagai berikut:

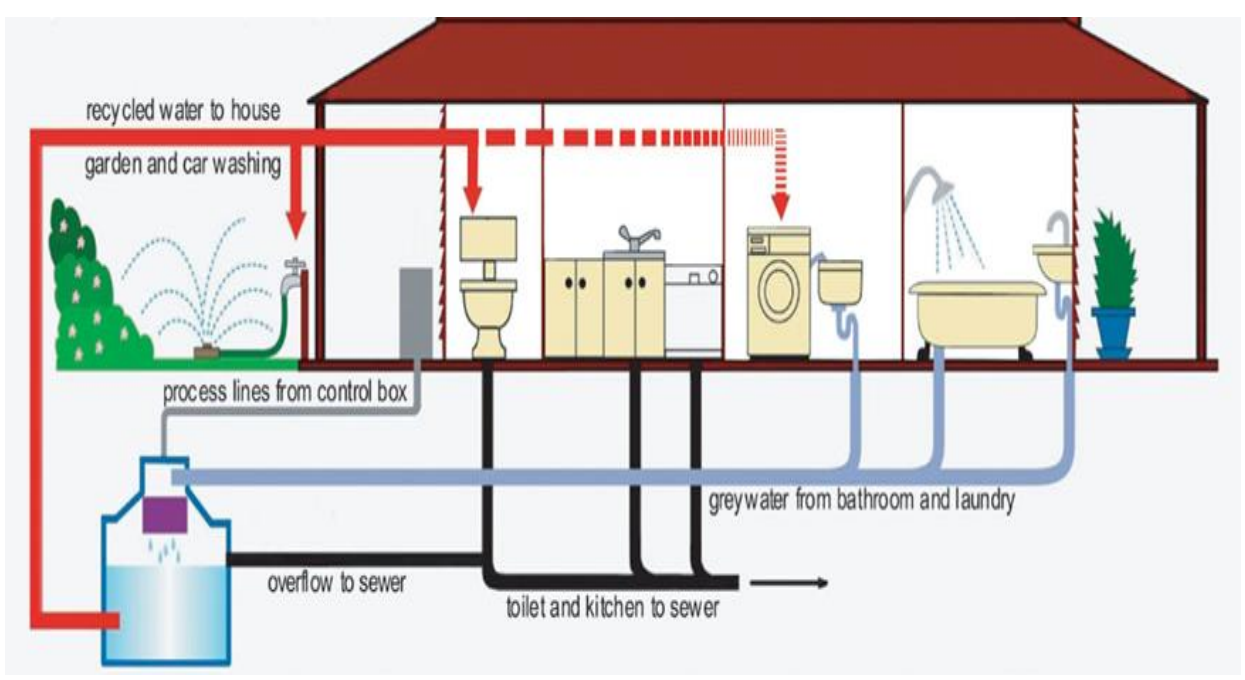

Gambar 1. Konsep Daur Ulang Air N.S.W Departement of Health

Sumber: Moersidik, 2009

Terkait dengan konsep daur ulang air yang akan digunakan kembali oleh masyarakat maka perlu diperhatikan spesifikasi penggunaan air yang dapat menggunakan air daur ulang, selain itu psikologis masyarakat yang takut menggunakan air daur ulang untuk memenuhi kebutuhan air juga dipertimbangkan. Menurut Middleton (2008) terdapat beberapa aktivitas manusia yang dapat menggunakan air daur ulang yaitu untuk menyiram pada kloset sehabis buang air, menyiram tanaman dan mencuci mobil. Jumlah air yang dapat di daur ulang adalah sebanyak 100 liter per orang setiap harinya, artinya setiap orang 
yang menggunakan daur ulang air hanya membutuhkan air setiap harinya sebanyak 75 liter per hari atau menghemat sebesar $57,24 \%$.

Pada penelitian ini juga digunakan beberapa asumsi sebagai berikut:

1. Air yang digunakan oleh masyarakat adalah air tanah dangkal;

2. Sumber air lainnya yang digunakan oleh masyarakat diabaikan;

3. Pada awal simulasi volume air tanah dianggap tidak ada stock, sebab tidak dilakukan pengukuran volume air tanah dangkal sebelum tahun 2003;

4. Jumlah penduduk dianggap sesuai dengan angka sensus BPS, proses keluar masuk penduduk lintas wilayah diabaikan.

5. Kemampuan lahan menyerap air didasarkan oleh penelitian Hidayat (2008).

\section{Tujuan permodelan}

Tujuan dari dibuatnya permodelan daya dukung air tanah dangkal di wilayah Jakarta Selatan adalah untuk mengetahui kemampuan air tanah dangkal dalam mendukung kehidupan masyarakat di Kotamadya Jakarta Selatan.

\section{Definisi konseptual}

a. Air tanah dalam Sukardi (1984) adalah air yang terdapat di bawah permukaan tanah dalam ruang antara pada suatu lajur jenuh. Air tanah berasal dari daur sistem adanya hujan, lahan, jenis tanah, batuan, dan lainnya.

b. Menurut UU No.32/2009, daya dukung lingkungan hidup adalah kemampuan lingkungan hidup untuk mendukung perikehidupan manusia, mahluk hidup lain, dan keseimbangan antarkeduanya. Sedangkan daya tampung lingkungan adalah kemampuan lingkungan hidup untuk menyerap zat, energi, dan / atau komponen lain yang masuk atau dimasukkan ke dalamnya.

c. Definisi kawasan perkotaan adalah wilayah yang yang memiliki kegiatan utama bukan pertanian dengan susunan fungsi kawasan sebagai tempat permukiman perkotaan, pemusatan dan distribusi pelayanan jasa pemerintahan, pelayanan sosial, dan kegiatan ekonomi. Kawasan perkotaan terdiri atas : 1) Kawasan lindung kota adalah kawasan lindung yang secara ekologis merupakan satu ekosistem yang terletak pada wilayah kota, kawasan lindung yang memberikan pelindungan terhadap kawasan bawahannya 
yang terletak di wilayah kota, dan kawasan-kawasan lindung lain yang menurut ketentuan peraturan perundang-undangan pengelolaannya merupakan kewenangan pemerintah daerah kota. 2) Kawasan budi daya kota adalah kawasan di wilayah kota yang ditetapkan dengan fungsi utama untuk dibudi dayakan atas dasar kondisi dan potensi sumber daya alam, sumber daya manusia, dan sumber daya buatan.

\section{Diagram Simpal Kausal (CLD)}

CLD dari permodelan daya dukung air tanah dangkal di wilayah Jakarta Selatan adalah sebagai berikut:

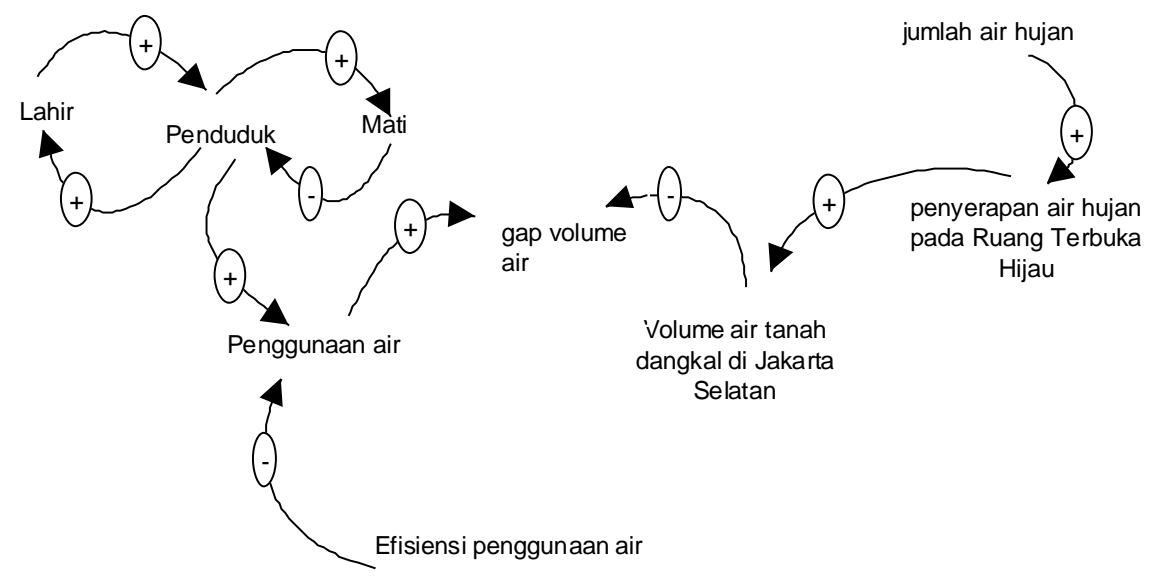

Gambar 2. CLD permodelan daya dukung air tanah dangkal di Jakarta Selatan

\section{Hubungan antar variabel}

Laju penambahan air tanah dangkal dipengaruhi oleh ruang terbuka hijau yang ada, semakin luas ruang terbuka hijau menambah volume air tanah dangkal yang ada. Penggunaan dari air tanah dangkal sangat dipengaruhi oleh jumlah penduduk dan efisiensi penggunaan air tanah dangkal tersebut.

\section{Strategi:}

Pada simulasi digambarkan bahwa kondisi sebelum tahun 2010, posisi penggunaan air tanah dangkal tanpa intervensi efisiensi daur ulang penggunaan air. Setelah 2011, diasumsikan kebijakan efisiensi penggunaan air tersebut diberlakukan. Fungsi IF yang digunakan adalah if pada fungsi waktu (time) 


\section{Stock Flow Diagram (SFD)}

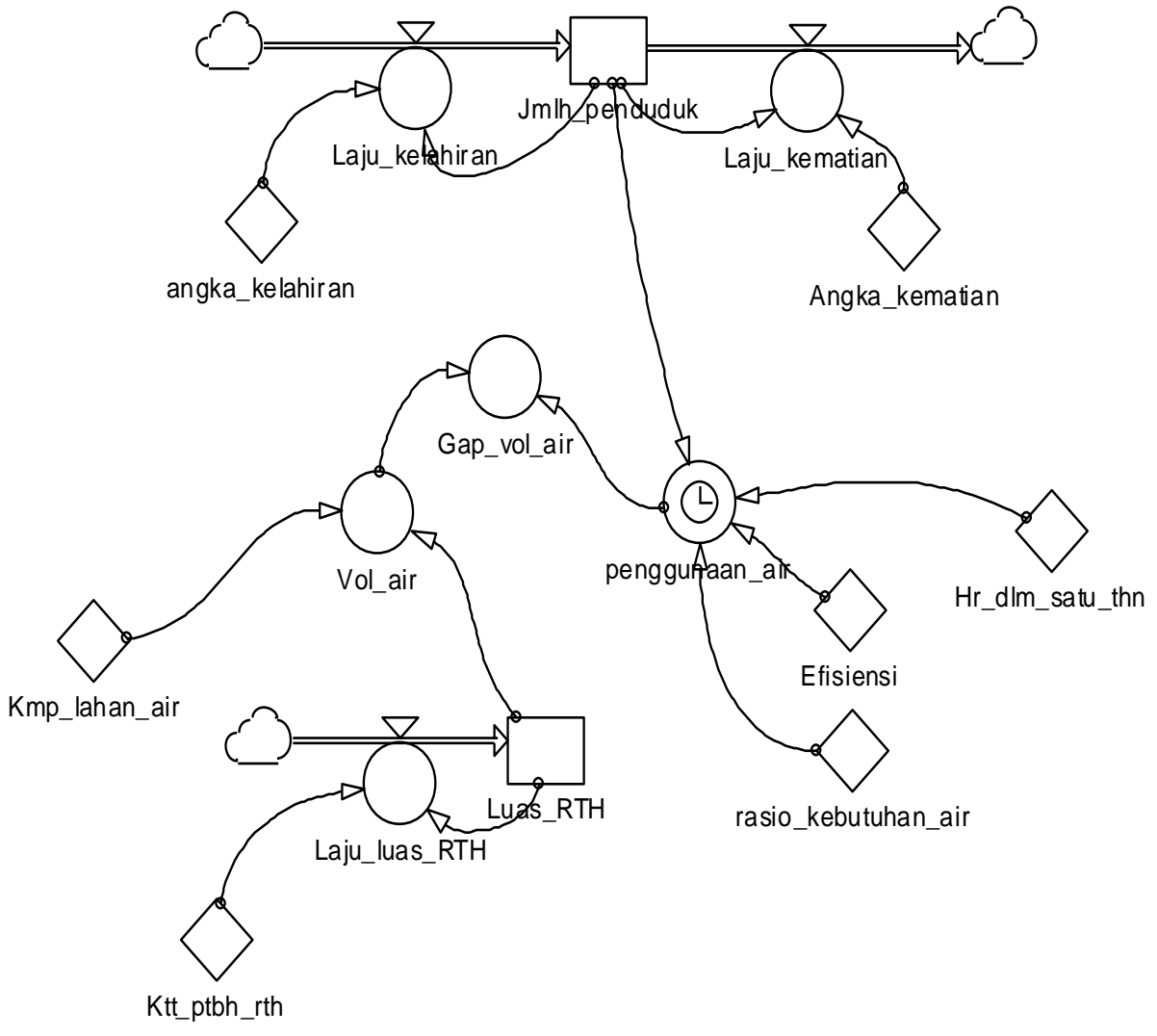

Gambar 3. Stock flow diagram permodelan

Pada Gambar 3 di atas, pada SFD telah dimasukkan variabel efisiensi sebagai intervensi untuk melakukan penghematan terhadap penggunaan air.

\section{PEMBAHASAN}

Pertumbuhan penduduk di wilayah Jakarta Selatan berdasarkan data time series dan hasil simulasi tahun 2003-2020 menunjukkan perilaku exponential growth. Hal ini disebabkan pertumbuhan penduduk terus meningkat. 


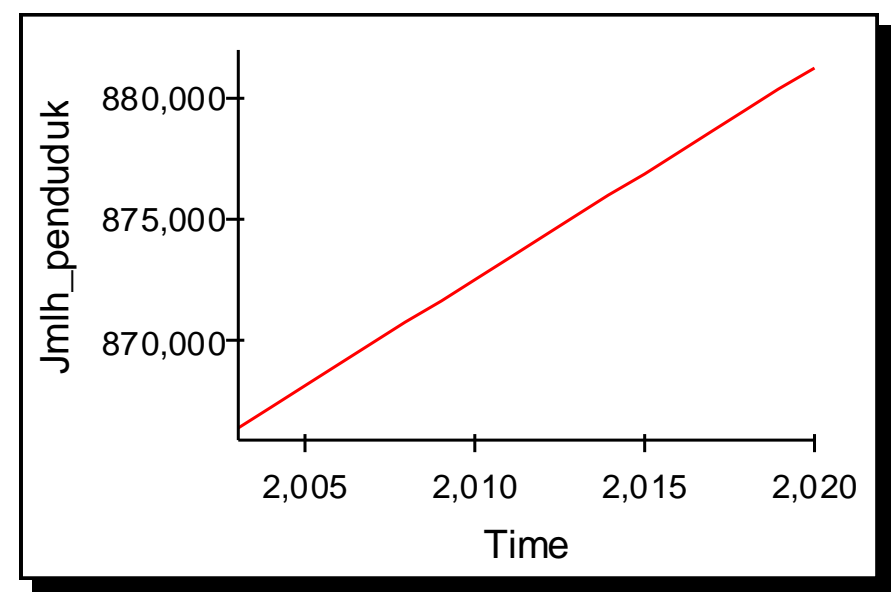

Gambar 4. Grafik pertumbuhan penduduk

Secara rincil data jumlah penduduk dapat dilihat pada Tabel 3.

Tabel 3. Data pertumbuhan penduduk pada tahun 2003-2020

\begin{tabular}{|c|r|l|}
\hline Time & Jmlh_penduduk & \\
\hline 2,003 & $866,515.00$ & \\
\hline 2,004 & $867,381.52$ & \\
\hline 2,005 & $868,248.90$ & \\
\hline 2,006 & $869,117.15$ & \\
\hline 2,007 & $869,986.26$ & \\
\hline 2,008 & $870,856.25$ & \\
\hline 2,009 & $871,727.11$ & \\
\hline 2,010 & $872,598.83$ & \\
\hline 2,011 & $873,471.43$ & \\
\hline 2,012 & $874,344.90$ & \\
\hline 2,013 & $875,219.25$ & \\
\hline 2,014 & $876,094.47$ & \\
\hline 2,015 & $876,970.56$ & \\
\hline 2,016 & $877,847.53$ & \\
\hline 2,017 & $878,725.38$ & \\
\hline 2,018 & $879,604.10$ & \\
\hline 2,019 & $880,483.71$ & \\
\hline 2,020 & $881,364.19$ & \\
\hline & & \\
\hline & & \\
\hline
\end{tabular}

Pada kondisi nyata, seiring dengan pertumbuhan penduduk, volume air tanah dangkal akan mengalami penurunan dan penggunaan air akan mengalami peningkatan, seperti pada Gambar 5. 


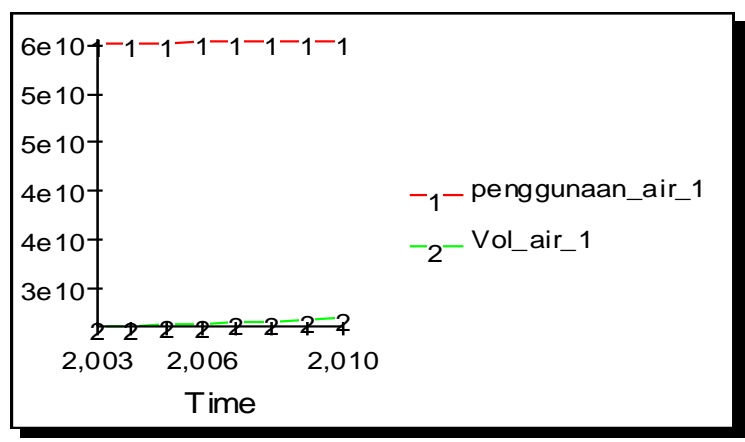

Gambar 5. Grafik selisih volume air dan penggunaan air pada tahun 2003-2010

Namun setelah dilakukan intervensi efisiensi penggunaan air setelah tahun 2010 akan terjadi pergeseran sebagaimana data dalam Tabel 4 dan grafik yang ditunjukkan pada Gambar 6.

Tabel 4. Data selisih volume air dengan penggunaan air

\begin{tabular}{|c|r|r|r|l|}
\hline Time & \multicolumn{1}{|c|}{ Vol_air } & penggunaan_air & Gap_vol_air & \\
\hline 2,003 & $26,231,400,000.00$ & $55,348,645,625.00$ & $-29,117,245,625.00$ & \\
\hline 2,004 & $26,362,557,000.00$ & $55,403,994,270.63$ & $-29,041,437,270.63$ & \\
\hline 2,005 & $26,494,369,785.00$ & $55,459,398,264.90$ & $-28,965,028,479.90$ & \\
\hline 2,006 & $26,626,841,633.93$ & $55,514,857,663.16$ & $-28,888,016,029.24$ & \\
\hline 2,007 & $26,759,975,842.09$ & $55,570,372,520.82$ & $-28,810,396,678.73$ & \\
\hline 2,008 & $26,893,775,721.31$ & $55,625,942,893.34$ & $-28,732,167,172.04$ & \\
\hline 2,009 & $27,028,244,599.91$ & $55,681,568,836.24$ & $-28,653,324,236.33$ & \\
\hline 2,010 & $27,163,385,822.91$ & $55,737,250,405.07$ & $-28,573,864,582.16$ & \\
\hline 2,011 & $27,299,202,752.03$ & $23,912,874,509.14$ & $3,386,328,242.89$ & \\
\hline 2,012 & $27,435,698,765.79$ & $23,936,787,383.65$ & $3,498,911,382.14$ & \\
\hline 2,013 & $27,572,877,259.61$ & $23,960,724,171.03$ & $3,612,153,088.58$ & \\
\hline 2,014 & $27,710,741,645.91$ & $23,984,684,895.20$ & $3,726,056,750.71$ & \\
\hline 2,015 & $27,849,295,354.14$ & $24,008,669,580.10$ & $3,840,625,774.05$ & \\
\hline 2,016 & $27,988,541,830.91$ & $24,032,678,249.68$ & $3,955,863,581.24$ & \\
\hline 2,017 & $28,128,484,540.07$ & $24,056,710,927.93$ & $4,071,773,612.14$ & \\
\hline 2,018 & $28,269,126,962.77$ & $24,080,767,638.86$ & $4,188,359,323.91$ & \\
\hline 2,019 & $28,410,472,597.58$ & $24,104,848,406.49$ & $4,305,624,191.09$ & \\
\hline 2,020 & $28,552,524,960.57$ & $24,128,953,254.90$ & $4,423,571,705.67$ & \\
\hline & & & & \\
& & & & \\
\hline
\end{tabular}

Berdasarkan data di atas, terlihat bahwa kebutuhan air terus meningkat dari tahun ke tahun berbanding lurus dengan peningkatan jumlah penduduk. Hal tersebut menjadi dasar diperlukan intervensi. Jika intervensi dilakukan maka akan terjadi penurunan jumlah 
penggunaan air, hasil intervensi dapat dilihat pada data tahun 2011. Sementara perbandingan antara jumlah volume air tanah dangkal dan penggunaan air dapat dilihat pada Gambar 6.

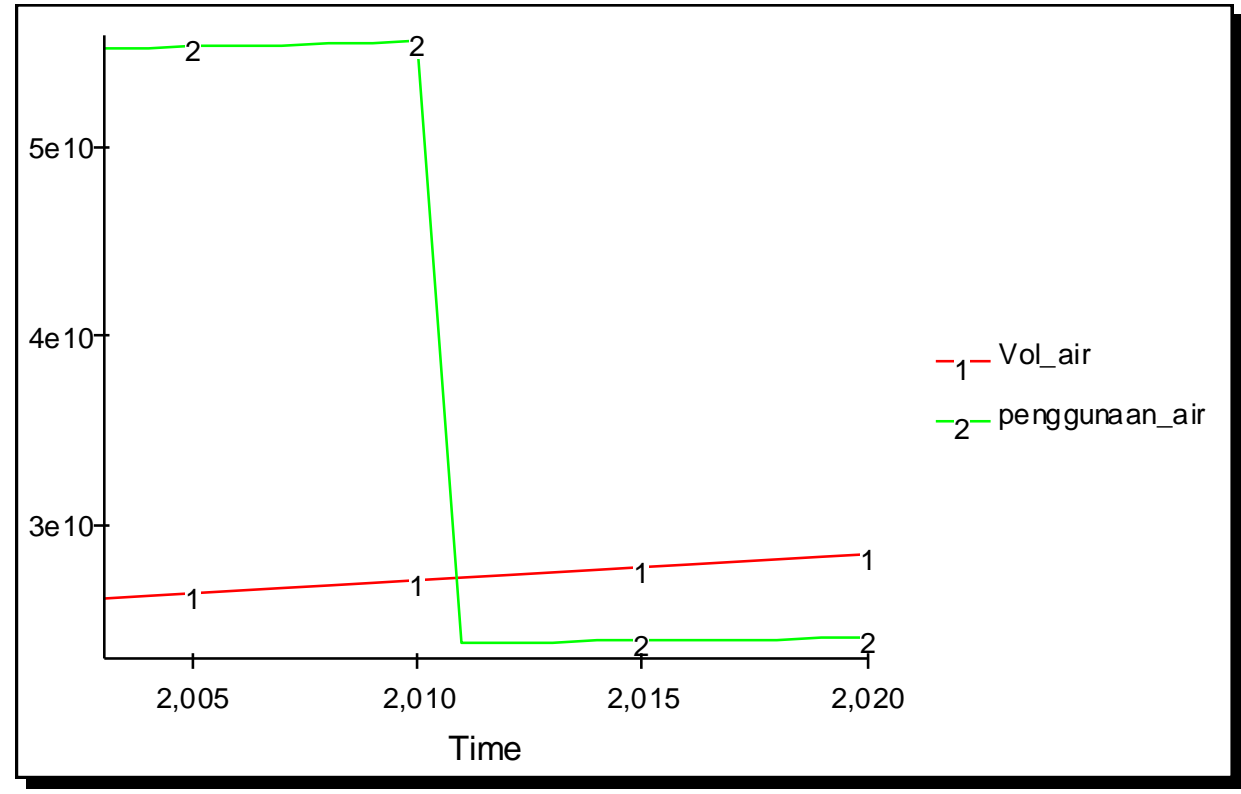

Gambar 6. Grafik perbandingan volume air tanah dangkal dan penggunaan air

\section{Validasi}

Berdasarkan hasil perhitungan pada proses validasi diperoleh bias antara 0,316345\% sampai dengan 2,599035687\%. Data tersebut masih menunjukkan angka di bawah 10\% sehingga data tersebut dapat dinyatakan valid dan dapat digunakan.

\section{KESIMPULAN}

Berdasarkan hasil simulasi dan asumsi yang berlaku dalam permodelan, kondisi air tanah dangkal di kotamadya Jakarta Selatan jika tidak dilakukan intervensi maka tidak akan mampu mendukung kehidupan masyarakat di kotamadya Jakarta Selatan. Apabila dilakukan intervensi maka akan dapat dilakukan penghematan dalam penggunaan air sehingga volume air tanah tidak akan terus menurun sehingga mampu mendukung kehidupan masyarakat kotamadya Jakarta Selatan.

\section{DAFTAR PUSTAKA}

Budihardjo, E \& DJ. Sujarto. 1999. Kota Berkelanjutan. Alumni. Bandung. 
Soemarwoto, O. 1992. Indonesia dalam kancah isu lingkungan global. Penerbit PT Gramedia Pustaka Utama. Jakarta.

Sukardi. 1984. Air Tanah. Direktorat Geologi Tata Lingkungan. Bandung.

Bower, H. 1978. Groundwater Hydrology. Mc Graw Hill Kogakusha LTD. New York. Tokyo.

Muhammadi, E. Aminullah, B. Soesilo. 2001. Analisa Sistem Dinamis Lingkungan Hidup, Sosial. Ekonomi, Management. UMJ Press. Jakarta.

Joga, N. 2007. Dari Kota Kelabu ke Kota Hijau. Harian Kompas, 2 November 2007

Suharto, B. S. 1997, Thesis: Faktor-faktor yang mempengaruhi simpanan air tanah (Studi kasus kota Jakarta dan sekitarnya). Pascasarjana Universitas Indonesia.

Hidayat, D. 2009. Thesis: Estimasi ruang terbuka hijau di Kotamadya Jakarta Selatan. Sekolah Pascasarjana IPB. Bogor 